\title{
The Centre-Periphery Dimension and Trust in Politicians: The Case of Norway
}

This is an Accepted Manuscript version (AM), please refer to the original article published in Territory, Politics, Governance June 2019. DOI:10.1080/21622671.2019.1624191

Keywords: Political trust, Geography, Norway, Centre, Periphery, Trust in politicians, Urban, Rural

Authors: 1) Jonas Stein, jonas.stein@uit.no - Department of Social Sciences, UiT - The Arctic University of Norway, Postboks 6050 Langnes, 9037 Tromsø, Norway

2) Marcus Buck, marcus.buck@uit.no - Department of Social Sciences, UiT - The Arctic University of Norway, Postboks 6050 Langnes, 9037 Tromsø, Norway

3) Hilde Bjørnå, hilde.bjorna@uit.no - Department of Social Sciences, UiT - The Arctic University of Norway, Postboks 6050 Langnes, 9037 Tromsø, Norway

Institutional affiliation: UiT - The Arctic University of Norway (all authors)

Contact: Jonas Stein, jonas.stein@uit.no - Department of Social Sciences, UiT - The Arctic University of Norway, Postboks 6050 Langnes, 9037 Tromsø, Norway, Telephone:

$+4748064583$

ORCID: https://orcid.org/0000-0003-2902-042X

Twitter: https://twitter.com/TromsoJonas

Acknowledgments: We thank the anonymous referees for useful suggestions and comments that have significantly improved the paper. We would also like to thank participants at NOPSA 2017 for comments on an earlier draft of this paper, and Tor Midtbø for consecutive comments and suggestions throughout the writing process. 


\title{
The Centre-Periphery Dimension and Trust in Politicians: The Case of Norway
}

\begin{abstract}
Scholars have often studied social, political and economic factors affecting trust. This article considers the relationship between spatial location and trust in politicians. We hypothesise that the centre-periphery framework developed by Stein Rokkan has explanatory value for the study of trust in politicians. By using multilevel regression analysis on a large- $\mathrm{N}$ survey on a crucial case (Norway), the article controls for the urban-rural divide and cultural, institutional, political and economic factors at both the individual and municipal levels. Our findings indicate that spatial location manifests itself as a unique explanatory variable and that the peripheral regional location (i.e., distance from the political centre) matters more for spatial differences in trust in politicians than the urban-rural divide. The spatial dimension of political trust could be considered as an additional factor for explaining differences in trust in politicians.
\end{abstract}

Keywords: political trust; geography; centre; periphery; trust in politicians; urban; rural; distance; Norway 


\section{Introduction}

While high levels of political trust are considered an essential component of a wellfunctioning society, there is a growing sense that such trust is deteriorating in contemporary democracies (Hardin, 2013; Klingemann, 1999; Lipset and Schneider, 1983; Norris, 1999; Nye, Zelikow, \& King, 1997; Pharr and Putnam, 2000; Torcal, 2014), albeit less so in the Nordic countries (Dalton, 2005). Understanding the causes behind political trust is of interest not only for political scientists but also for governments and citizens in general.

Here, we understand political trust to be the public sentiment about the (local and national) government and its political representatives (Turper and Aarts, 2017). Political trust is often explained in relation to government performance and citizens' normative expectations (Hetherington, 1998; Rothstein, 2011), in relation to cultural norms and early-life socialisation (Almond and Verba, 2015; Inglehart, 1997; Mishler and Rose, 2001; Putnam, 2001) or in relation to political and electoral variables (Listhaug, 1995; Miller and Listhaug, 1990; Newton and Norris, 2000). The spatial aspects of political systems, however, have mainly been relegated to control variables linked to urban versus rural residence (e.g.Delhey and Newton, 2005; Hooghe, Marien, \& de Vroome, 2012).

Here, we turn the tables and explore the explanatory power of the centre-periphery divide on citizens' trust in local and national politicians. We hypothesise that even though government performance, cultural and political variables certainly have a strong influence on trust in politicians, their explanatory powers are not fully sufficient to explain political trust formation. This article highlights the spatial dimension of trust and that regional spatial location (in a centre-periphery framework) could be considered an additional independent variable for explaining trust in politicians. More specifically, the spatial location could be measured in terms of the distance from the capital.

The centre-periphery framework has long been important to political scholars (Iversen, 1994; Keating, 1998; Lipset and Rokkan, 1967). Especially Rokkan and Urwin (1983) argued that the peripheral 'predicament' itself is a distinct factor that must be considered when explaining various political systems and outcomes. Rokkan (1999) argued that in all European countries, the nation-building process yielded a centre-periphery tension between the capital region and peripheral regions, and that this tension was key in the formation of the political system. 
We have chosen Norway as a case for this study, as we agree with Eckstein (2015) that the particular blend of division and cohesion in Norwegian democracy renders it a good crucial case to explore the validity of general hypotheses and theories (see Gerring, 2007 for discussion). Past trust studies have also used Norway as an exploratory case (Denters, 2002; Høyer and Mønness, 2016). In addition, the peripheries of interest in this study are not highly mobilised regions demanding full independence, and we therefore avoid the problems associated with deviant or extreme cases (George and Bennett, 2005). Norway used to be spatially divided with regard to political identities but now generally demonstrates high average levels of trust in both government institutions and politicians (Dalton, 2005; Torcal, 2014). Generous policies for promoting social cohesion and regional development have been established (Eriksen, 1996). Thus, there are many arguments for why there should be no spatial differences in political trust in Norway today. To explore the relationship between the centre-periphery dimension and political trust, we have applied a multilevel regression analysis on a survey (Difi, 2015) with 20,604 Norwegian respondents on level 1 (individual data). On level 2 (municipality data), we have used public data from 427 Norwegian municipalities to explore social and economic explanations for spatial differences in trust in politicians.

The remainder of the paper is structured as follows: First a broader conceptual and theoretical framework for the centre-periphery theory, other theories of political trust and the case of Norway; then accounts for the data collection and the methods applied; afterwards the main results are presented and discussed. Finally there is the conclusion.

\section{Theoretical and Empirical Framework}

The Centre-Periphery Perspective

The centre-periphery dimension of the modern nation-state is first and foremost linked to the work of Stein Rokkan. Rokkan's most important contribution to political analysis was the addition of an independent territorial dimension to politics: the centre-periphery axis linking the institutional architecture of a nation-state to its territorial structure (i.e., its given political and spatial characteristics) (Rokkan, 1987a, 1999). The theoretical salience of the centreperiphery nexus is that the existence of a political centre logically presupposes a periphery and vice versa. The two are interdependent. Centre, as much as periphery, is a dependent variable in macro-historical terms. 
From this follows that, as any collective distinction may serve as the underpinning for political mobilisation (Sartori, 1975), differing historiographies linked to this process may create territorially different political interests. Hence, political actors who perceive themselves as 'representatives of peripheries' tend to nurture the idea that different interests linked to territories have developed over time. A form of spatial identity is thus an asset in the regional political mobilisation against the centralising efforts of the state.

Jennings and Stoker (2016) argued that there is a divide between the citizens residing in locations that are strongly connected to global growth and others that are not, and that a divide exists between those from densely populated urban centres with an emerging knowledge economy and those living in suburban communities, coastal areas and post-industrial towns. The latter group holds different values and feel 'left behind' in political visions and strategies (Jennings and Stoker, 2017b, 4-5). In Britain, this manifests in the geographical polarisation of voting behaviour. The geographical polarisation of votes is an expression of disappointment and distrust in the trends in the economic-, educational- and social areas and illustrates disintegration; place-based experiences provide a dynamic that is pulling the cosmopolitan and 'left-behind' locations further apart (Jennings and Stoker, 2016; RodríguezPose, 2018). As Jennings and Stoker (2017a) argue, this disintegration is due to vast global economic, cultural and social shifts: The economic in terms of divides between the knowledge/change economy and the traditional stable economy; the social in terms of divides in patterns of immigration and education; and the cultural in terms of divides between those with social liberal identities in the urban areas and those with traditionalist identities linked to ancestry and birthplace.

In line with the Rokkan perspective, we argue that regional disintegration might also be persistent and enduring; it builds on much the same mechanisms argued by Jennings and Stoker but is deep-seated and connected to the history of regions and their distance from the centre. While disintegration needs constant attention and accommodation from the centre to be overcome, the conception of 'us' in the region and 'the elites' in the centre may never be removed. According to the Rokkanian perspective, the regional identities are formed by economic, political and cultural tensions in relation to the centre. The degree of political representation in central government bodies matters, as does economic distribution.

According to this perspective, the cultural tensions refer to the centre's lack of integration and respect for regional cultural expressions. Such local cultural expressions are found in religious 
practices, language and local traditions. Regional identities building on an opposition to the centre can potentially mobilise against national strategeis and spur mistrust in central government.

Whether the peripheral actors choose and succeed in mobilising on a territorial basis largely depends on the status of the periphery vis-à-vis the state in the various phases of the process of modernisation. In the struggle over the identity of the citizenry, the individual is subject to the pull of different identity-construction forces. As the centre-periphery power relationship is asymmetrical, factors such as distance, difference and dependence mean that the political discourse in the periphery tends to revolve around this very relationship. Rokkan and Urwin (1983) have shown how this dimension has contributed to the development of the political system and party structure in Western Europe. Recent political events like the referendums on independence in Catalonia (2018) and Scotland (2014) exemplify how the centre-periphery tensions are not only part of the contemporary political climate, but in some cases have turned into a manifest cleavage that structures politics within long-established European states. However, this centre-periphery dimension has not been analysed with regard to political trust. If this tension continues to affect the contemporary political organisation, electoral system and party structure, it is reasonable to assume that it might also affect the trust people have in the politicians operating within that system. In other words, it is reasonable to assume that the centre-periphery tensions spill over to political trust.

Examining whether there is a difference in political trust between the centre and peripheral regions is the first step in the analysis. There are several explanations for why spatial differences possibly exist. First, socioeconomic characteristics might explain some differences in trust, as they are not evenly distributed within the country. Studies should also control for differences in structural variables, such as age and gender. Dalton (2005) in particular has shown how higher education is strongly correlated with higher levels of trust. Second, another spatial dimension of politics, namely the urban-rural divide, could explain regional differences. The transformation from agricultural to industrialised society has induced a sense of loss and deprivation in many rural areas due to depopulation and a loss of influence in politics. Past studies of political trust have used urban-rural residence as a control variable (e.g.Delhey and Newton, 2005; Hooghe, et al., 2012). 
Third, studies have shown that economic inequalities help explain differences in trust (e.g. Barbara, 2006; Uslaner, 1999). Variables such as economic growth or unemployment could therefore hold explanatory power for regional variations in trust. Fourth, Kesler and Bloemraad (2010) found lower levels of societal trust in advanced democracies with higher levels of immigration; regional differences in immigration levels might explain differences in political trust.

Fifth, linked to the Rokkanian centre-periphery perspective, distance from the capital might explain differences in political trust. In the asymmetrical centre-periphery dimension linked to Rokkan's theories about state- and nation-building, both the urban and rural areas in the periphery are characterised by distance, difference and dependence in relation to the centre. Their ability to influence distant decisions made in the political centre potentially fosters a sense of powerlessness and exclusion from the political system. The distance from the capital would also be in line with James Scott's ideas about 'The Art of Not Being Governed', where the people are more sceptical regarding the powerful central state and government is more likely to move as far away from the political centre as possible (Scott, 2010).

\section{Cultural, Performance and Electoral Perspectives on Trust}

To be added to the theoretical arguments for why the centre-periphery dimension possibly has explanatory value for studies of political trust are other major theoretical explanations for differences in political trust. First, the cultural perspective on trust argues that trust in political institutions originates outside the political sphere and that trust is formed in long-standing and deep-seated beliefs about people that are rooted in cultural norms and communicated through early-life socialization (Almond and Verba, 2015; Inglehart, 1997; Mishler and Rose, 2001, 31; Putnam, 2001). This is a different understanding of culture than as found in the Rokkan perspective: The cultural perspective addresses a local social sphere and ties in society, not the centre's integration policies with respect to regional cultural expressions. The cultural perspective argues that loss of trust 'that reaches beyond the circle of personally known people' (generalised trust) is caused by inequalities that prevail in society (Uslaner, 2002). Cultural theories hypothesises that trust originates outside the political sphere; it is exogenous and an extension of interpersonal trust. One strand of these theories emphasises that trust is a collective property that is broadly shared by all members of society, while another argues that trust varies among citizens and is based on differences in socialisation, background, experiences and the like. Interpersonal trust is further assumed to transfer into political 
institutions and to create a civic culture (Almond and Verba, 2015). This is what Putnam argues; that interpersonal trust spills over into co-operation in bowling leagues, choirs and voluntary organisations, and 'spills up' to political institutions (Helliwell and Putnam, 1995; Putnam, 1993). He identified membership in voluntary associations as a proxy for having higher trust individually and in society. Our study, hypothesising that regional spatial location might be an additional independent variable for explaining political trust, controls for membership in voluntary associations.

Second, the government performance perspective on trust (Van Ryzin, 2007), sometimes called the institutional perspective (Mishler and Rose, 2001), hypothesise that trust originates as an outcome of successful policies, that it is a consequence of institutional performance and that it is politically endogenous. Trust in institutions is rationally based; it hinges on how citizens evaluate institutional performance. Institutions that perform well generate trust; untrustworthy institutions generate scepticism and distrust (Hetherington, 1998; North, 1990; Rothstein, 2011; Van Ryzin, 2007). One strand of the perspective on government performance emphasises that trust in institutions varies across countries and must be regarded as an aggregate evaluation of the outputs of political institutions (success of government policies in matters like promoting growth, efficiency and avoiding corruption). Others argue that trust in institutions varies both within and across countries by individual tastes and experiences, attitudes, and individual social and economic position (Mishler and Rose, 2001). Political trust is often associated with trust in government (Nevitte and Kanji, 2002); a low level of trust in one institution is usually followed by low levels of trust in other institutions (Denters, Gabriel, \& Torcal, 2007; Hetherington, 1998), and trust in institutions spills over to trust in politicians. The performance position has strong connotations with what Caramani (2004) described as the 'nationalization of politics,' where major national factors explain differences, thereby rendering internal spatial location unimportant.

Third, studies of political trust have shown that political variables concerning elections are expected to provide a better explanation for different levels of political trust than demographic variables (Listhaug, 1995; Miller and Listhaug, 1990; Newton and Norris, 2000). Anderson (2005) argues that losing elections generates ambivalent attitudes towards political authorities. People who vote for parties that form a government ('electoral winners') tend to develop more positive attitudes to the political system, whereas those voting for parties that do not gain governmental power ('electoral losers') become more cynical. Those who abstain from 
voting also tend to have lower trust in politicians (Grönlund and Setälä, 2007). Many studies (Inglehart and Norris, 2016; Mudde, 2004, 2007) concerning the emerging populist or rightwing parties emphasise their distrust in politicians and the political system as important factors for their success. Their supporters have lower political trust, as also found in empirical studies in Scandinavia and Europe (Söderlund and Kestilä-Kekkonen, 2009).

Both the performance and electoral perspectives should be considered mediator variables (Baron and Kenny, 1986). If living in the periphery is associated with lower trust in government and governmental institutions, it is reasonable to assume that those living in the periphery also display lower trust in the central government by abstaining from elections, voting for protest parties and/or dissatisfaction with public services. Consequently, when added to the model, these variables would predict peripheral status to have less effect.

\section{The Spatial Dimension of Trust in Local Politicians}

We also observe that the political trust concept is discussed less in relation to regional and local political actors and institutions. However, a study on Norway, Denmark, Netherlands and the United Kingdom by Denters (2002) has shown that trust in local officeholders was typically (often considerably) higher than trust in national officeholders. This finding corresponds to predictions in political economy theory regarding the effect of size on satisfaction (Mouritzen, 1989); and satisfaction, as we have seen, is linked to trust in a performance perspective. Here, the most relevant political economy arguments are that smaller political units are more in accordance with citizen preferences. Small political systems force people to reveal their true preferences (Søndergaard, 1982) and are characterised by a closer relationship between political representatives and citizens; that is, that policies tend to correspond to the preferences of the citizens (V. Ostrom, Tiebout, \& Warren, 1961). And further, that smaller political units are ideal for education to democracy, producing responsible citizens and opportunities for participation (Mill, 1861; Sharpe, 1970), whereas larger units produce alienation, cynicism and frustration (Mouritzen, 1989). Local governments offer benefits that citizens appreciate; they facilitate local adaptations and variations, facilitate citizen influence and participation, and they facilitate coordination efficiency. The cultural perspective emphasising the importance of societal trust for political trust also resonates with the idea of there being higher trust in local politicians who live their everyday lives in the local community and are connected with their voters. Hence, it is of 
interest whether citizens in the periphery exhibit higher trust in their local politicians than in national politicians.

The differences in trust between local and national politicians are not thoroughly considered in Rokkan's theories about the nation-building process and the centre-periphery conflict. The mechanism that would explain equal (or perhaps lower) trust in politicians in the periphery relative to the centre is deducted from the reform theory perspective (Mouritzen, 1989; E. J. Ostrom, 1972), arguing that larger political unit policies have greater impact and more effective service production than smaller ones. The Norwegian central government regulates many local policy fields tightly (e.g., schools and health care), as do most European countries, leaving local governments with limited autonomy. This likely constitutes a perception of local representatives more as brokers for the central government than advocates of the interests in the periphery (particularly if they are elected on the tickets of the nation-wide parties) and a perception of local goverments as less significant. This leads to indifference when it comes trustworthiness. This explanation corresponds to the Rokkanian assumption about asymmetrical power structures between centre and periphery, and perceptions in the periphery as local governments being powerless and an extended arm of the central authority (Rokkan and Urwin, 1983). It is also worth noting that smaller political units are more likely to be homogenous as opposed to larger, more hetrogenous units (Dahl and Tufte, 1973); and similarly, there is a chance of there being less diversity with respect to citizen preferences in smaller political units. A local government is therefore more likely to become a so-called 'tyranny of the majority' than a central government, which in itself can spur distrust in local governments.

\section{Empirical Approach and The Case of Norway}

As mentioned, Rokkan detected the centre-periphery dimension in his studies on Norway. This dimension has been salient in Norwegian politics, as national governments have proposed and implemented policies aimed explicitly at remedying the centre-periphery divide (Eriksen, 1996; Teigen, 2011; Valen, 1973). For our purposes, Norway is an appropriate case, also because all of the Norwegian municipalities, regardless of size, have the same responsibilities. Hence, trust in local politicians is easily comparable between municipalities and with national politicians. Further, the conditions in Norway are appropriate for investigating the centre-periphery as a unique explanatory variable for political trust, as it is likely that there should actually be no spatial differences regarding political trust. Trust levels 
in Scandinavia are among the highest in the world, and the high level of political trust is often ascribed to 'good government' (Rothstein and Stolle, 2003). High levels of socioeconomic resources, social security, income equality, civil liberties and gender equality (Sides, 1999) are embedded in state institutions and are crucial elements in generalised trust formation. The Scandinavian welfare model (Esping-Andersen, 2013) is universal in its character and essential for promoting social and spatial equality (Martin and Sunley, 1998). Norway (along with the other Scandinavian countries) has implemented explicit policies for limiting spatial inequalities within the country. Combined with good data on the individual and municipal level, this makes Norway a good case for exploring the relationship between the centreperiphery dimension and political trust on the national and local levels.

Figure 1: Center-periphery - Rokkan model

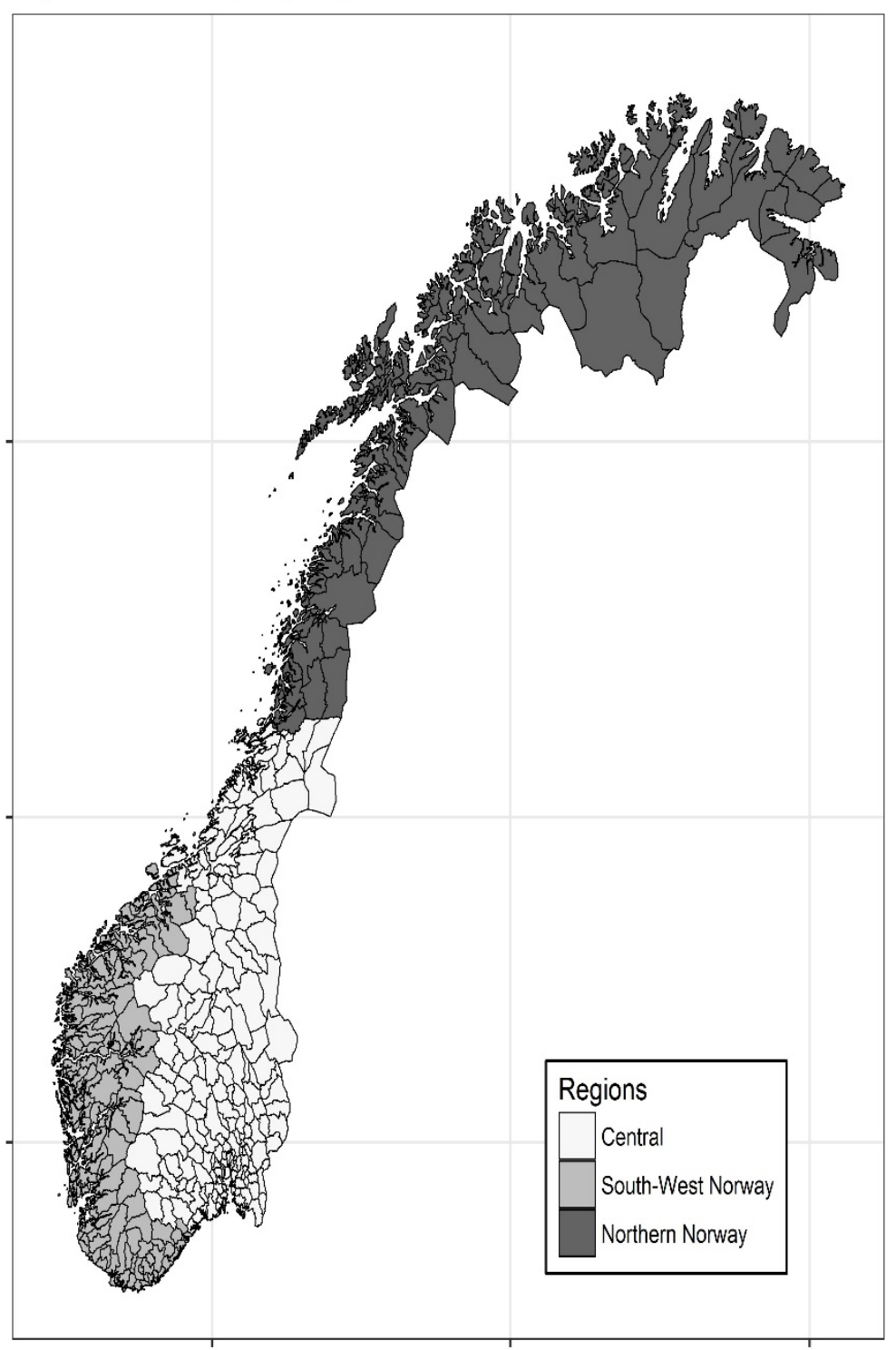


Rokkan defined two peripheral regions in Norway: Northern Norway and South-West Norway (see figure 1). South-West Norway was regarded as a cultural periphery marked by alternative standards, such as language (Nynorsk), lay Christianity, and temperance. Northern Norway was seen as an economically backward periphery marked by class polarisation. Regarding accommodation into the Norwegian political system, the two peripheries have fared differently. The cultural standards of the South-West were acknowledged relatively early in terms of the right to establish lay churches outside the official state church, a quota for Nynorsk in public administration, schools, and in national broadcasting as well as the right to ban alcohol locally. The establishment of both organised interest groups and a proper political party, the Christian Democratic Party (from 1933), further ensured that these cultural standards were voiced in the political system. The South-West has become a prosperous region with high incomes and population growth due to the hydrocarbon industry (Eurostat, 2017).

The Northern periphery has only seen sporadic and unsuccessful attempts at party-building to voice regional interests (Aune-listen and The Coastal Party) and has historically been marked by lower voter turnout in parliamentary elections (Buck, 2013) and slow demographic development compared to the rest of the country (Stein, 2019). However, the peripheral distinctiveness in Northern Norway has been used successfully for political mobilisation against the political centre in Oslo on two occasions. In the Norwegian referendums about EEC/EU membership in 1972 and 1994, the opposition was particularly strong in the peripheral areas and even more so in the north, where more than 70 per cent of the population voted against EU membership (Jenssen and Valen, 1995; Valen, 1973). After the 1972 debacle, Northern Norway benefited from large economic transfers in regional development funds from the centre. From a centre-periphery perspective, however, such funds could lead to a client-patron relationship (Eriksen, 1996), resulting in both increased dependency and mutual distrust. Since the two peripheries have had different political experiences, we expect the citizens of the Northern periphery to display lower levels of trust in politicians than those in the South-West periphery and the rest of the country. Thus, based on the theoretical framework above, we have developed the following two main hypotheses.

H1: Respondents in the Northern periphery exhibit lower levels of trust in national politicians than respondents in the rest of Norway. 
H2: Respondents in both peripheries exhibit higher trust in local politicians than in national politicians.

As a part of Hypothesis H1, we have derived five sub-hypotheses for exploring the causes of lower levels of trust in the peripheral regions:

H1a: The lower levels of trust in national politicians are explained by socioeconomic and demographic differences.

H1b: The lower levels of trust in national politicians are explained by the urban-rural divide. H1c: The lower levels of trust in national politicians are explained by differences in economic development and growth.

H1d: The lower levels of trust in national politicians are explained by differences in immigration settlement.

H1e: The lower levels of trust in national politicians are explained by the long distance from the capital (Oslo).

\section{Methods and Data}

As mentioned above, scholars have debated how to measure political trust. We find the argument for creating an average of the levels of confidence that individuals have for a set of different political institutions compelling (Bovens and Wille, 2008; Catterberg and Moreno, 2006; Marien and Hooghe, 2011; Van der Brug and Van Praag, 2007). Although there are important similarities, trust in political actors, in liberal democratic institutions, and in the courts and police may vary (Denters, et al., 2007). Nevertheless, we have chosen to use a single-item variable, 'trust in politicians', as an indicator of the concept of political trust (other studies with single-item indicators Hetherington and Rudolph, 2008; Newton, 2001; Rudolph and Evans, 2005; Van der Meer, 2010). To compare trust between the local and national levels, it is necessary to have a comparable question to use to create the dependent variable. Consequently, we cannot say that our findings are valid for all types of political trust. Specifically, trust in local politicians is measured in terms of the question 'How much or little trust do you have that politicians in your municipality are working for the citizens' best interests?' (all questions answered on a scale from 1-7). Trust in national politicians is measured by the question 'How much or little trust do you have that politicians in Stortinget [the national parliament] are working for citizens' best interests?' (all questions answered on a scale from 1-7). Our data came from the Norwegian Agency for Public Management and eGovernment's citizen surveys (Difi, 2015) and included 20,744 respondents from all of the 
Norwegian municipalities. The survey was conducted in two rounds (2013 and 2015). Since there is almost no difference between the two waves (we have run models with a year dummy showing similar results), the responses have been pooled together for the analysis. The participants were a random sample drawn from the Norwegian population over age 18 and invited by e-mail to respond to the citizen's survey. They could choose to respond by mail or online (see Appendix 1 for more specific information about the variables used in this survey).

In the analysis, we have used a multilevel regression model with the respondents at level 1 (i) and the 427 municipalities at level 2 (j). All of the independent variables (except 2) are significant in bivariate models (see Appendix 2), and we have also run the different models with various centring as well. ${ }^{1}$ All of the models are estimated by maximum likelihood procedure (ML). They have also been run with restricted maximum likelihood procedure (REML), which produced the same results. The basic model takes the general form:

Level 1: $\mathrm{Y}_{\mathrm{ij}}=\beta_{0 \mathrm{j}}+\beta 1 \mathrm{j} \mathrm{X}_{\mathrm{ij}}+\mathrm{r}_{\mathrm{ij}}$

Level 2: $\beta_{0 \mathrm{j}}=\gamma_{00}+\gamma 01 \mathrm{~W}_{\mathrm{j}}+\mathrm{u}_{0 \mathrm{j}}$

$$
\beta_{1 \mathrm{j}}=\gamma_{10}+\gamma 11 \mathrm{~W}_{\mathrm{j}}+\mathrm{u}_{1 \mathrm{j}}
$$

The modelling strategy has been to begin with exploring if there are regional differences in trust in national politicians. In model 1, we have used Rokkan’s definition of functional peripheries in Norway to create two dichotomous variables: Northern Norway and SouthWest Norway. Northern Norway is defined as the three northernmost counties (Finnmark, Troms, and Nordland). This definition is consistent with Rokkan's periphery and is a level-2 region in Eurostat NUTS classification. The definition of South-West Norway is the same as used by Rokkan, that is, it consists of the six counties: Hordaland, Møre og Romsdal, Sogn og Fjordane, Rogaland, Vest-Agder and Aust-Agder (Rokkan, 1987b).

Second, individual control variables like age, income and education are added to the model. We have also added a variable for urban-rural divide by adding the respondent's residence (on a 1-6 scale depending on how rural they live). To control for cultural theories, it would have been preferable to have a variable for societal trust. Unfortunately, there is no such variable in this dataset. We have therefore used voluntary association membership as a proxy

\footnotetext{
${ }^{1}$ All of our models have also been run with mean-centring of age, satisfaction with government services and trust in national politicians.
} 
variable, as others have done (Baumgartner and Walker, 1988), before us which is also in line with Putnam (2001).

As mentioned above, some variables could be considered mediator variables, meaning that when they are added to the model not only do we expect them to have explanatory power in themselves but we also predict a decline in the strength of the effect of Northern Norway. In model 3, the variable satisfaction with government services is used to assess public performance. For electoral factors, we have defined right-wing voter as a voter for the Norwegian Progress Party (Frp), government party voter as voting for Conservative Party, Liberal Party, Christian People’s Party or the Progress Party, and abstainer as anyone who said they had the right to vote but abstained from doing so. Here, the data is slightly susceptible due to the well-known tendency for surveys to underestimate the abstention rate (e.g. Granberg and Holmberg, 1991; Himmelweit, Biberian, \& Stockdale, 1978).

In models 4-9, we try to dig deeper and based on the hypotheses in chapter 2 we try to remove any significant independent centre-periphery effect, by adding one variable at a time on level 2. To control for economic inequalities, we have used GDP (at county level) as a variable (there are 19 counties in Norway, three of which are in Northern Norway), and we have also used another economic variable: municipal unemployment rate (model 5). As some studies (Kesler and Bloemraad, 2010) indicate that differences in immigration could influence trust, this is also controlled for in terms of the percentage of municipal population classified as immigrants (model 6). In the last models (7-9), we have explored the travelling distance (in km) by car from the capital (Oslo) to the town hall in the municipality (using Open Street Maps).

To be able to analyse our $\mathrm{H} 2$ about the relative differences in trust between local and national politicians, we have applied the same modelling strategy as in our analysis of trust in national politicians. The dependent variable is defined as

Difference trust $=$ trust in local politicians - trust in national politicians 


\section{Results}

Table 1: Regression Results

\begin{tabular}{|c|c|c|c|c|c|c|c|c|c|}
\hline & & & & Dep & oendent vari & iable: & & & \\
\hline & & & & Trust in & n national pc & oliticians & & & \\
\hline & (1) & (2) & (3) & (4) & (5) & (6) & (7) & (8) & (9) \\
\hline Northern Norway & $-0.22^{* * *}$ & $-0.20^{* * *}$ & $-0.15^{* * *}$ & $-0.15^{* * *}$ & $-0.15^{* * *}$ & $-0.15^{* * *}$ & -0.09 & -0.01 & \\
\hline & $(0.05)$ & $(0.05)$ & $(0.04)$ & $(0.04)$ & $(0.04)$ & $(0.04)$ & (0.09) & $(0.21)$ & \\
\hline $\begin{array}{l}\text { South-West } \\
\text { Norway }\end{array}$ & -0.05 & -0.03 & -0.01 & -0.02 & -0.02 & -0.01 & -0.0004 & -0.01 & 0.02 \\
\hline & $(0.04)$ & $(0.03)$ & $(0.03)$ & $(0.03)$ & $(0.03)$ & $(0.03)$ & $(0.04)$ & $(0.04)$ & $(0.03)$ \\
\hline Rurality & & $-0.03^{* * *}$ & -0.01 & -0.01 & -0.01 & -0.01 & -0.01 & -0.01 & -0.01 \\
\hline & & $(0.01)$ & $(0.01)$ & $(0.01)$ & $(0.01)$ & $(0.01)$ & $(0.01)$ & $(0.01)$ & $(0.01)$ \\
\hline Higher Education & & $0.38^{* * *}$ & $0.23^{* * *}$ & $0.23^{* * *}$ & $0.23^{* * *}$ & $0.23^{* * *}$ & $0.23^{* * *}$ & $0.23^{* * *}$ & $0.23^{* * *}$ \\
\hline & & $(0.03)$ & $(0.02)$ & $(0.02)$ & $(0.02)$ & $(0.02)$ & $(0.02)$ & $(0.02)$ & $(0.02)$ \\
\hline Age & & $-0.001^{* *}$ & -0.0005 & -0.0005 & -0.0005 & -0.0005 & -0.001 & -0.001 & -0.001 \\
\hline & & $(0.001)$ & $(0.001)$ & $(0.001)$ & $(0.001)$ & $(0.001)$ & $(0.001)$ & $(0.001)$ & $(0.001)$ \\
\hline Income & & -0.003 & 0.005 & 0.004 & 0.004 & 0.004 & 0.004 & 0.004 & 0.004 \\
\hline & & $(0.01)$ & $(0.005)$ & $(0.005)$ & $(0.005)$ & $(0.005)$ & $(0.005)$ & $(0.005)$ & $(0.005)$ \\
\hline Woman & & 0.01 & 0.01 & 0.01 & 0.01 & 0.01 & 0.01 & 0.01 & 0.01 \\
\hline & & $(0.02)$ & $(0.02)$ & $(0.02)$ & $(0.02)$ & $(0.02)$ & $(0.02)$ & $(0.02)$ & $(0.02)$ \\
\hline $\begin{array}{l}\text { Membership in } \\
\text { voluntary assoc }\end{array}$ & & $0.10^{* * *}$ & $0.04^{*}$ & $0.04^{*}$ & $0.04^{*}$ & $0.04^{*}$ & $0.04^{*}$ & $0.04^{*}$ & $0.04^{*}$ \\
\hline & & $(0.02)$ & $(0.02)$ & $(0.02)$ & $(0.02)$ & $(0.02)$ & $(0.02)$ & $(0.02)$ & $(0.02)$ \\
\hline $\begin{array}{l}\text { Satisfaction with } \\
\text { government serv }\end{array}$ & & & $0.80^{* * *}$ & $0.80^{* * *}$ & $0.80^{* * *}$ & $0.80^{* * *}$ & $0.80^{* * *}$ & $0.80^{* * * *}$ & $0.80^{* * *}$ \\
\hline & & & $(0.01)$ & $(0.01)$ & $(0.01)$ & $(0.01)$ & $(0.01)$ & $(0.01)$ & $(0.01)$ \\
\hline Right wing voter & & & $-0.45^{* * *}$ & $-0.45^{* * *}$ & $-0.45^{* * *}$ & $-0.45^{* * *}$ & $-0.45^{* * *}$ & $-0.45^{* * *}$ & $-0.45^{* * *}$ \\
\hline & & & $(0.04)$ & $(0.04)$ & $(0.04)$ & $(0.04)$ & $(0.04)$ & $(0.04)$ & $(0.04)$ \\
\hline $\begin{array}{l}\text { Government party } \\
\text { voter }\end{array}$ & & & -0.01 & -0.01 & -0.01 & -0.01 & -0.01 & -0.01 & -0.01 \\
\hline & & & $(0.02)$ & $(0.02)$ & $(0.02)$ & $(0.02)$ & $(0.02)$ & $(0.02)$ & $(0.02)$ \\
\hline Abstainer & & & $-0.39^{* * *}$ & $-0.39^{* * *}$ & $-0.39^{* * *}$ & $-0.39^{* * *}$ & $-0.39^{* * *}$ & $-0.39^{* * *}$ & $-0.39^{* * *}$ \\
\hline & & & $(0.05)$ & $(0.05)$ & $(0.05)$ & $(0.05)$ & $(0.05)$ & $(0.05)$ & $(0.05)$ \\
\hline GDP (county level) & & & & 0.001 & 0.001 & 0.001 & 0.001 & 0.001 & 0.001 \\
\hline & & & & $(0.001)$ & $(0.001)$ & $(0.002)$ & $(0.002)$ & $(0.002)$ & $(0.002)$ \\
\hline $\begin{array}{l}\text { Municipal } \\
\text { unemployment }\end{array}$ & & & & & -0.02 & -0.02 & -0.02 & -0.02 & -0.02 \\
\hline & & & & & $(0.02)$ & $(0.02)$ & $(0.02)$ & $(0.02)$ & $(0.02)$ \\
\hline $\begin{array}{l}\text { Percentage classifed } \\
\text { as immigrants }\end{array}$ & & & & & & 0.001 & -0.0001 & 0.0005 & -0.001 \\
\hline & & & & & & $(0.003)$ & $(0.003)$ & $(0.004)$ & $(0.003)$ \\
\hline $\begin{array}{l}\text { Distance from } \\
\text { capital(in } 100 \mathrm{~km} \text { ) }\end{array}$ & & & & & & & -0.01 & -0.003 & $-0.01^{* * *}$ \\
\hline & & & & & & & $(0.01)$ & $(0.01)$ & $(0.003)$ \\
\hline $\begin{array}{l}\text { Interaction term } \\
\text { Distance*North }\end{array}$ & & & & & & & & -0.01 & \\
\hline & & & & & & & & $(0.02)$ & \\
\hline Constant & $4.25^{* * *}$ & $4.26^{* * *}$ & $0.21^{* * *}$ & 0.09 & 0.13 & 0.14 & 0.16 & 0.16 & 0.16 \\
\hline & $(0.02)$ & $(0.07)$ & $(0.07)$ & $(0.16)$ & $(0.16)$ & $(0.17)$ & $(0.17)$ & $(0.17)$ & $(0.17)$ \\
\hline Observations & 20,744 & 17,935 & 17,225 & 17,225 & 17,225 & 17,225 & 17,225 & 17,225 & 17,225 \\
\hline Log Likelihood & $-39,374.13$ & $-33,641.27$ & $-28,967.39$ & $-28,967.00$ & $-28,966.62$ & $-28,966.60$ & $-28,966.38$ & $-28,966.29$ & $-28,966.82$ \\
\hline Akaike Inf. Crit. & $78,758.27$ & $67,304.55$ & $57,964.79$ & $57,966.01$ & $57,967.23$ & $57,969.20$ & $57,970.76$ & $57,972.59$ & $57,969.64$ \\
\hline
\end{tabular}


Model 1 shows a negative effect of Northern Norway on trust in national politicians, but no effect of the variable South-West Norway. As Rokkan suggested, even though Northern Norway and South-West Norway are peripheries, they are different kinds of peripheries. Respondents in the cultural periphery in South-West Norway do not have significantly lower trust in national politicians. In model 2, individual level controls for socioeconomic characteristics and cultural theories are added to the model. As expected, some of them (higher education, membership in voluntary associations and rurality) have explanatory power. At the same time, it is worth noting that the negative effect of Northern Norway remains significant. When the mediator variables are added to the model in model 3, we find that all of them (except government-party voter) hold explanatory power and, as predicted, there is a decline in the strength of the effect of Northern Norway after adding those variables.

However, a significant effect of Northern Norway remains after adding the control and mediator variables. This seems to support the more general hypothesis $\mathrm{H} 1$, that there is significantly lower trust in national politicians in Northern Norway. As it can be explained by neither socioeconomic or demographic differences nor the urban-rural divide (see model 2), H1a and H1b must be rejected. Adding economic variables (models 4 and 5) does not change the results. The same goes when immigration is added in model 6. Consequently, H1c and H1d are rejected.

When the distance from the capital is added in model 7, the dummy variable Northern Norway becomes insignificant. Using an interaction term in model 8, the peripheral indicator is insignificant and close to zero. In model 9, Northern Norway is left out of the model and distance from the capital becomes a significant variable for lower trust in national politicians. This seems to confirm H1e, according to which lower levels of trust in national politicians are explained by the long distance from the capital (Oslo). Distance from the capital is obviously correlated with the dummy variable Northern Norway (corr=0.82). In the appendix 3 the same models are run with distance from the capital being logarithmically transformed, which reduces the collinearity (corr $=0.47$ ), but displaying similar results. 


\begin{tabular}{|c|c|c|c|c|c|c|}
\hline & \multicolumn{6}{|c|}{ Dependent variable: } \\
\hline & \multicolumn{6}{|c|}{ Difference in trust between national and local } \\
\hline & $(10)$ & $(11)$ & $(12)$ & (13) & $(14)$ & (15) \\
\hline \multirow[t]{2}{*}{ Northern Norway } & 0.03 & 0.06 & -0.24 & 0.05 & & \\
\hline & $(0.07)$ & $(0.08)$ & $(0.18)$ & $(0.07)$ & & \\
\hline \multirow[t]{2}{*}{ South-West Norway } & -0.04 & -0.06 & -0.10 & & & \\
\hline & $(0.05)$ & $(0.06)$ & $(0.07)$ & & & \\
\hline \multirow[t]{2}{*}{ Rurality } & & -0.02 & -0.02 & & 0.004 & \\
\hline & & $(0.01)$ & $(0.01)$ & & $(0.01)$ & \\
\hline \multirow[t]{2}{*}{ Higher Education } & & $-0.21^{* * *}$ & $-0.22^{* * *}$ & & & \\
\hline & & $(0.03)$ & $(0.03)$ & & & \\
\hline \multirow[t]{2}{*}{ Age } & & 0.001 & 0.001 & & & \\
\hline & & $(0.001)$ & $(0.001)$ & & & \\
\hline \multirow[t]{2}{*}{ Income } & & $-0.02^{* * *}$ & $-0.02^{* * *}$ & & & \\
\hline & & $(0.01)$ & $(0.01)$ & & & \\
\hline \multirow[t]{2}{*}{ Woman } & & 0.01 & 0.01 & & & \\
\hline & & $(0.02)$ & $(0.02)$ & & & \\
\hline \multirow[t]{2}{*}{ Membership in voluntary associations } & & 0.01 & 0.01 & & & \\
\hline & & $(0.02)$ & $(0.02)$ & & & \\
\hline \multirow[t]{2}{*}{ Satisfaction with government services } & & $-0.13^{* * *}$ & $-0.13^{* * *}$ & & & \\
\hline & & $(0.01)$ & $(0.01)$ & & & \\
\hline \multirow[t]{2}{*}{ Right wing voter } & & 0.06 & 0.07 & & & \\
\hline & & $(0.04)$ & $(0.04)$ & & & \\
\hline \multirow[t]{2}{*}{ Government party voter } & & $0.20^{* * *}$ & $0.20^{* * *}$ & & & \\
\hline & & $(0.03)$ & $(0.03)$ & & & \\
\hline \multirow[t]{2}{*}{ Abstainer } & & $0.23^{* * *}$ & $0.23^{* * *}$ & & & \\
\hline & & $(0.06)$ & $(0.06)$ & & & \\
\hline \multirow[t]{2}{*}{ GDP (county level) } & & & -0.003 & & & \\
\hline & & & $(0.004)$ & & & \\
\hline \multirow[t]{2}{*}{ Municipal unemployment } & & & $-0.21^{* * *}$ & & & \\
\hline & & & $(0.04)$ & & & \\
\hline \multirow[t]{2}{*}{ Percentage of population classifed as immigrants } & & & $0.02^{* * *}$ & & & \\
\hline & & & $(0.01)$ & & & \\
\hline \multirow[t]{2}{*}{ Distance from capital (in 100 km) } & & & $0.03^{* *}$ & & & 0.01 \\
\hline & & & $(0.02)$ & & & $(0.01)$ \\
\hline \multirow[t]{2}{*}{ Constant } & $0.22^{* * *}$ & $0.98^{* * *}$ & $1.31^{* * *}$ & $0.20^{* * *}$ & $0.19^{* * *}$ & $0.18^{* * *}$ \\
\hline & $(0.04)$ & $(0.10)$ & $(0.35)$ & $(0.03)$ & $(0.06)$ & $(0.04)$ \\
\hline Observations & 18,589 & 15,765 & 15,765 & 18,589 & 18,473 & 18,589 \\
\hline Log Likelihood & $-33,646.57$ & $-28,172.57$ & $-28,159.57$ & $-33,646.89$ & $-33,428.34$ & $-33,646.54$ \\
\hline Akaike Inf. Crit. & $67,303.14$ & $56,375.14$ & $56,357.13$ & $67,301.79$ & $66,864.69$ & $67,301.08$ \\
\hline Bayesian Inf. Crit. & $67,342.29$ & $56,490.12$ & $56,502.78$ & $67,333.11$ & $66,895.98$ & $67,332.40$ \\
\hline
\end{tabular}

Models 10 to 12 show our findings for differences in trust between national and local politicians. There are small differences as to which variables explain differences in political 
trust between local and national politicians. Even though the distance from the capital is significant in model 12, it is not significant in the bivariate model (model 15). The other spatial variables (Northern Norway and Rurality) hold no significant explanatory power in any of the models. This indicates that the spatial dimension is relatively limited for explaining differences in trust between national and local politicians.

\section{The Spatial Dimension of Trust in Politicians}

Based on our models, our findings indicate that there is a centre-periphery dimension for the explanation for some of the differences regarding trust in politicians. These findings are in line with theories emphasising the spatial dimension of politics (Agnew, 1987; Iversen, 1994; Lipset and Rokkan, 1967; Rokkan, 1987a). Despite decades of so-called 'cohesion policy' and the development of a universal welfare system - the latter created to even-out social and spatial inequalities - we still find a significant spatial independent variable. The coefficient effect of the dummy variable is only 0.15 on a 1-7 scale (model 3), indicating that while significant, the difference does not represent an unsurmountable cleavage in trust. In general trust in politicians is high in Norway, even though it is slightly lower amongst people living in Northern Norway, one of two peripheral regions defined by (Rokkan, 1987b), trust nationallevel politicians less despite relevant control and mediator variables. This suggests that what Caramani (2004) described as the 'nationalization of politics', making internal spatial location unimportant, cannot be taken for granted. It suggests that regional disintegration might be persistent and enduring; the conception of 'us' in the region and 'the elites' in the centre is deep-seated and may never disappear.

Our models have also tried to investigate what characterise the peripheral dimension of trust in politicians. As model 7 illustrates, when the variable distance from the capital is added to the model, the dummy variable becomes insignificant. The AIC and BIC basically being the same in model 6 (with Northern Norway and without distance) and model 9 (without Northern Norway and with distance) indicates that the general variable distance from the capital could replace the more case-specific variable, Northern Norway. This could mean that distance from the political centre matters more for explaining territorial differences in trust in politicians than economic and cultural factors. As Scott (2010) has shown, those who are more sceptical of the powerful central state and the government are more likely to move farther from the political centre. And this might also work the other way around; that the distance causes those living far away from the political centre to become more sceptical of 
institutions controlled from far away and that they feel that they have limited influence on those institutions.

It is also worth noting that the lower level of trust in national politicians in the peripheral region is similar to the level of trust in their local politicians. Again, this might indicate that local politicians are perceived less as defenders of the periphery and more as the extended arm of the central authorities (Rokkan and Urwin, 1983). The trust in local politicians is strongly correlated with trust in national politicians, and the relative differences are explained by performance (Denters, et al., 2007; Hetherington, 1998; Rothstein, 2011) and political factors (Anderson, 2005; Newton and Norris, 2000; Söderlund and Kestilä-Kekkonen, 2009). In all of the models for trust in both national and local politicians, the rurality variable is insignificant when controlling for cultural, performance and political factors. This indicates that some of the theoretical assumptions about the salience of small jurisdictions for trust in local democracy are weakened empirically. This might indicate that local politicians are perceived as insignificant or as brokers for the central government.

The spatial perspective has not been thoroughly studied in the trust literature other than sometimes as an urban-rural control variable in empirical studies (e.g.Delhey and Newton, 2005; Hooghe, et al., 2012). Keating (2018) noted that in most of the social sciences, space has merely been treated as 'where things happened', rather than something with explanatory capacity. He argued that space should be seen as not merely a topological category but as a social and political construct, the meaning of which is given by its content. By exploring the spatial dimension with regard to trust in politicians, our findings suggest that space could be a political construct and, in this case, that the most important spatial component is the region's distance from the political centre, not the urban-rural divide. We also note that regional and municipal differences regarding economic performances and migration do not explain differences in political trust; at least not in a relatively egalitarian country like Norway.

In cross-country studies, many scholars have assumed that there is no regional difference between respondents within the same country. Adding a regional level in multilevel models might allow for more nuanced analyses. If there is a regional effect with regard to political trust in a rather homogenous, rich and politically stable country like Norway, where the peripheral regions are not highly politically mobilised, one should take the possible effects of 
the centre-periphery dimension into account when studying differences in political trust in general.

\section{Conclusion}

Our study indicates that spatial location matters and suggests that lower levels of trust in politicians in peripheral regions cannot be accounted for entirely by the major theories of political trust. We find that the analyses have theoretical implications that go beyond current government performance, cultural and political explanations for the level of political trust, as our study deals with the uniqueness of space as a variable. It suggests that there are spill-over effects of centre-periphery tensions to political trust and that the distance from the political centre matters for variations in trust in politicians. The theorised spill-over effects in the cultural and performance perspective - that is, that interpersonal trust and trust in institutions spill over to trust in politicians - lacks this spatial dimension. Our study suggests an additional explanation for political trust.

In addressing our case, we were looking particularly for the spatial dimension of political trust. Using a model with 15 different control and mediator variables, we were able to confirm our initial hypotheses that regional spatial location (in a centre-periphery framework) represents an additional independent variable that accounts for variations in trust in politicians. Furthermore, we asked if respondents in the Northern periphery display lower levels of trust in national politicians than those in the rest of Norway, which we found that they did. We found that the specific variable (Northern Norway) could be replaced by a more universal variable: the distance from the capital (Oslo). This also means that the more general finding from this paper is that the distance to the central government seems to matter for individual political trust. We also asked whether peripheries display higher trust in local politicians than in national politicians and found that they did not. We ascribe this finding to political factors and explanatory variables in the performance perspective: We do not write off essential elements in other theoretical perspectives.

As to our methods, we acknowledge that there could be some sources of minor inaccuracies in some of the control variables and that additional control variables (e.g., societal trust) could be added. However, in a model with 15 different control and mediator variables, we believe that our general findings are solid and robust. This is a crucial case study, and single case studies like this are limited with regard to generalisations, while the real need is to fashion 
generalisations with universal scope and validity. While we agree with this objection, single case studies are useful as a first step and may be followed up by replications in different settings (Lijphart, 1975).

This article has focused on the centre-periphery dimension for political trust in Norway. The centre-periphery relationship is part of all nation-building processes, and our finding is that it still seems to matter for social identities and trust, also after controlling for important socioeconomic factors and alternative theories. A more comprehensive analysis (e.g., including more countries or other types of trust) could lead to a deeper understanding of the relationship between peripheral regions and political trust formation. 


\section{References}

Agnew, J. (1987). Place and politics Boston: Allen and Unwin.

Almond, G. A., \& Verba, S. (2015). The civic culture: Political attitudes and democracy in five nations Princeton: Princeton university press.

Anderson, C. (2005). Losers' consent: Elections and democratic legitimacy Oxford: Oxford University Press on Demand.

Barbara, A. (2006). Diverse Communities. The problem with social capital: Cambridge New York: Cambridge University Press.

Baron, R. M., \& Kenny, D. A. (1986). The moderator-mediator variable distinction in social psychological research: Conceptual, strategic, and statistical considerations. Journal of personality and social psychology, 51(6), p 1173.

Baumgartner, F. R., \& Walker, J. L. (1988). Survey research and membership in voluntary associations. American Journal of Political Science, pp. 908-928.

Bovens, M., \& Wille, A. (2008). Deciphering the Dutch drop: Ten explanations for decreasing political trust in the Netherlands. International review of administrative sciences, 74(2), pp. 283-305.

Buck, M. (2013). Politisk mobilisering i Nord-Norge 1945-2009: En demokratisk periferi? In S. Jentoft, J.-I. Nergård \& K. A. Røvik (Eds.), Hvor går Nord-Norge? (Vol. 3, pp. 155-168). Stamsund: Orkana Akademisk.

Caramani, D. (2004). The nationalization of politics: The formation of national electorates and party systems in Western Europe Cambridge: Cambridge University Press.

Catterberg, G., \& Moreno, A. (2006). The individual bases of political trust: Trends in new and established democracies. International Journal of Public Opinion Research, 18(1), pp. 31-48.

Dahl, R. A., \& Tufte, E. R. (1973). Size and democracy Stanford: Stanford University Press.

Dalton, R. J. (2005). The social transformation of trust in government. International Review of Sociology, 15(1), pp. 133-154.

Delhey, J., \& Newton, K. (2005). Predicting cross-national levels of social trust: global pattern or Nordic exceptionalism? European Sociological Review, 21(4), pp. 311-327.

Denters, B. (2002). Size and political trust: evidence from Denmark, the Netherlands, Norway, and the United Kingdom. Environment and Planning C: Government and Policy, 20(6), pp. 793-812.

Denters, B., Gabriel, O., \& Torcal, M. (2007). Political confidence in representative democracies. In J. W. Van Deth, J. R. Montero \& A. Westholm (Eds.), Citizenship and involvement in European democracies. A comparative analysis (pp. 66-87).

Difi. (2015). Innbyggerundersøkelsen [Data set]. Retrieved from https://www.difi.no/rapporter-og-statistikk/undersokelser/innbyggerundersokelsen$\underline{2015}$

Eckstein, H. (2015). Division and cohesion in democracy: A study of Norway Princeton: Princeton University Press.

Eriksen, E. O. (1996). Det nye Nord-Norge: Avhengighet og modernisering i nord. In E. O. Eriksen (Ed.), Avhengighet og modernisering i nord (pp. 150-180). Bergen: Fagbokforlaget.

Esping-Andersen, G. (2013). The three worlds of welfare capitalism New York: John Wiley \& Sons.

Eurostat. (2017). Gross domestic product (GDP) at current market prices by NUTS 2 regions [Data set]. Retrieved from http://appsso.eurostat.ec.europa.eu/nui/show.do?dataset=nama_10r_2gdp\&lang=en

George, A. L., \& Bennett, A. (2005). Case studies and theory development in the social sciences Cambridge MA: MIT Press. 
Gerring, J. (2007). Is there a (viable) crucial-case method? Comparative political studies, 40(3), pp. 231-253.

Granberg, D., \& Holmberg, S. (1991). Self-reported turnout and voter validation. American Journal of Political Science, 35(2), pp. 448-459.

Grönlund, K., \& Setälä, M. (2007). Political trust, satisfaction and voter turnout. Comparative European Politics, 5(4), pp. 400-422.

Hardin, R. (2013). Government without trust. Journal of Trust Research, 3(1), pp. 32-52. doi:10.1080/21515581.2013.771502 Retrieved from https://doi.org/10.1080/21515581.2013.771502

Helliwell, J. F., \& Putnam, R. D. (1995). Economic growth and social capital in Italy. Eastern economic journal, 21(3), pp. 295-307.

Hetherington, M. J. (1998). The political relevance of political trust. American Political Science Review, 92(4), pp. 791-808.

Hetherington, M. J., \& Rudolph, T. J. (2008). Priming, performance, and the dynamics of political trust. The Journal of Politics, 70(2), pp. 498-512.

Himmelweit, H. T., Biberian, M. J., \& Stockdale, J. (1978). Memory for Past Vote: Implications of a Study of Bias in Recall. British Journal of Political Science, 8(3), pp. 365-375. doi:10.1017/S0007123400001411 Retrieved from https://www.cambridge.org/core/article/memory-for-past-vote-implications-of-astudy-of-bias-in-recall/80FA5A33D95AC772D489B54905E5C12A

Hooghe, M., Marien, S., \& de Vroome, T. (2012). The cognitive basis of trust. The relation between education, cognitive ability, and generalized and political trust. Intelligence, 40(6), pp. 604-613.

Høyer, H. C., \& Mønness, E. (2016). Trust in public institutions - spillover and bandwidth. Journal of Trust Research, 6(2), pp. 151-166. doi:10.1080/21515581.2016.1156546 Retrieved from https://doi.org/10.1080/21515581.2016.1156546

Inglehart, R. (1997). Modernization and postmodernization: Cultural, economic, and political change in 43 societies Princeton: Princeton University Press.

Inglehart, R., \& Norris, P. (2016). Trump, Brexit, and the rise of populism: Economic havenots and cultural backlash. Paper presented at 2016 meeting of the American Political Science Assocation.

Iversen, T. (1994). The logics of electoral politics: Spatial, directional, and mobilizational effects. Comparative political studies, 27(2), pp. 155-189.

Jennings, W., \& Stoker, G. (2016). The bifurcation of politics: two Englands. The Political Quarterly, 87(3), pp. 372-382.

Jennings, W., \& Stoker, G. (2017a). The new economy, social change, and polarised places: A changed terrain for British politics. Renewal, 25(3/4), pp. 28-43.

Jennings, W., \& Stoker, G. (2017b). Tilting towards the cosmopolitan axis? Political change in England and the 2017 general election. The Political Quarterly, 88(3), pp. 359-369.

Jenssen, A. T., \& Valen, H. (1995). Brussel midt imot: folkeavstemningen om EU Oslo: Ad Notam Gyldendal.

Keating, M. (1998). The new regionalism in Western Europe: territorial restructuring and political change: E. Elgar Cheltenham, UK.

Keating, M. (2018). Time, space and methodological pluralism. Territory, Politics, Governance, 6(3), pp. 277-278. doi:10.1080/21622671.2018.1488459 Retrieved from https://doi.org/10.1080/21622671.2018.1488459

Kesler, C., \& Bloemraad, I. (2010). Does immigration erode social capital? The conditional effects of immigration-generated diversity on trust, membership, and participation across 19 countries, 1981-2000. Canadian Journal of Political Science/Revue canadienne de science politique, 43(2), pp. 319-347. 
Klingemann, H.-D. (1999). Mapping political support in the 1990s: A global analysis. In P. Norris (Ed.), Critical citizens: Global support for democratic government (pp. 31-56).

Lijphart, A. (1975). II. The comparable-cases strategy in comparative research. Comparative political studies, 8(2), pp. 158-177.

Lipset, S., \& Rokkan, S. (1967). Cleavage structures, party systems, and voter alignments: an introduction New York: Free Press.

Lipset, S., \& Schneider, W. (1983). The decline of confidence in American institutions. Political Science Quarterly, 98(3), pp. 379-402.

Listhaug, O. (1995). The dynamics of trust in politicians. In H.-D. Klingemann \& D. Fuchs (Eds.), Citizens and the state (pp. 261-297). Oxford: Oxford University Press.

Marien, S., \& Hooghe, M. (2011). Does political trust matter? An empirical investigation into the relation between political trust and support for law compliance. European Journal of Political Research, 50(2), pp. 267-291.

Martin, R., \& Sunley, P. (1998). Slow convergence? The new endogenous growth theory and regional development. Economic geography, 74(3), pp. 201-227.

Mill, J. S. (1861). Considerations on representative government London: Parker and Son.

Miller, A. H., \& Listhaug, O. (1990). Political parties and confidence in government: A comparison of Norway, Sweden and the United States. British Journal of Political Science, 20(3), pp. 357-386.

Mishler, W., \& Rose, R. (2001). What are the origins of political trust? Testing institutional and cultural theories in post-communist societies. Comparative political studies, 34(1), pp. 30-62.

Mouritzen, P. E. (1989). City size and citizens' satisfaction: two competing theories revisited. European Journal of Political Research, 17(6), pp. 661-688.

Mudde, C. (2004). The populist zeitgeist. Government and opposition, 39(4), pp. 541-563.

Mudde, C. (2007). Populist radical right parties in Europe: Cambridge University Press Cambridge.

Nevitte, N., \& Kanji, M. (2002). Authority orientations and political support: A cross-national analysis of satisfaction with governments and democracy. Comparative Sociology, 1(3), pp. 387-412.

Newton, K. (2001). Trust, social capital, civil society, and democracy. International Political Science Review, 22(2), pp. 201-214.

Newton, K., \& Norris, P. (2000). Confidence in public institutions. In S. J. Pharr \& R. D. Putnam (Eds.), Disaffected democracies. What's troubling the trilateral countries. Princeton: Princeton University Press.

Norris, P. (1999). Critical citizens: Global support for democratic government Oxford: Oxford University Press.

North, D. C. (1990). A transaction cost theory of politics. Journal of theoretical politics, 2(4), pp. 355-367.

Nye, J. S., Zelikow, P., \& King, D. C. (1997). Why people don't trust government Cambridge, MA: Harvard University Press.

Ostrom, E. J. (1972). Metropolitan reform: Propositions derived from two traditions. Social Science Quarterly, 53(3), pp. 474-493.

Ostrom, V., Tiebout, C. M., \& Warren, R. (1961). The organization of government in metropolitan areas: a theoretical inquiry. American Political Science Review, 55(4), pp. 831-842.

Pharr, S. J., \& Putnam, R. D. (2000). Disaffected democracies: what's troubling the trilateral countries? Princeton: Princeton University Press.

Putnam, R. D. (1993). The prosperous community. The american prospect, 4(13), pp. 35-42. 
Putnam, R. D. (2001). Bowling alone: The collapse and revival of American community New York: Simon and Schuster.

Rodríguez-Pose, A. (2018). The revenge of the places that don't matter (and what to do about it). Cambridge Journal of Regions, Economy and Society, 11(1), pp. 189-209.

Rokkan, S. (1987a). Centre-periphery structures in Europe: An ISSC workbook in comparative analysis Frankfurt Am Main: Campus Verlag.

Rokkan, S. (1987b). Stat, nasjon, klasse Oslo: Universitetsforlaget.

Rokkan, S. (1999). State formation, nation-building, and mass politics in Europe: the theory of Stein Rokkan: based on his collected works Oxford: Clarendon Press.

Rokkan, S., \& Urwin, D. W. (1983). Economy, territory, identity: Politics of West European peripheries London: Sage Publications.

Rothstein, B. (2011). The quality of government: Corruption, social trust, and inequality in international perspective Chicago: University of Chicago Press.

Rothstein, B., \& Stolle, D. (2003). Social capital, impartiality and the welfare state: An institutional approach. In M. Hooghe \& D. Stolle (Eds.), Generating social capital (pp. 191-209). New York: Palgrave Macmillan.

Rudolph, T. J., \& Evans, J. (2005). Political trust, ideology, and public support for government spending. American Journal of Political Science, 49(3), pp. 660-671.

Sartori, G. (1975). Parties and party systems: A framework for analysis Cambridge: Cambridge University Press.

Scott, J. C. (2010). The art of not being governed: An anarchist history of upland Southeast Asia Singapore: Nus Press.

Sharpe, L. J. (1970). Theories and values of local government. Political Studies, 18(2), pp. 153-174.

Sides, J. (1999). It takes two: The reciprocal relationship between Social Capital and Democracy. UC Berkeley. Retrieved from https://escholarship.org/uc/item/2z6534q2

Stein, J. (2019). The Striking Similarities between Northern Norway and Northern Sweden. Arctic Review on Law and Politics, 10, pp. 79-102. doi:10.23865/arctic.v10.1247 Retrieved from https://arcticreview.no/index.php/arctic/article/view/1247

Söderlund, P., \& Kestilä-Kekkonen, E. (2009). Dark Side of Party Identification? An Empirical Study of Political Trust among Radical Right-Wing Voters. Journal of Elections, Public Opinion and Parties, 19(2), pp. 159-181.

Søndergaard, J. (1982). 'Kommunernes politiske ledelse - et miniportraet’. In P. E. Mouritzen (Ed.), Kommunalpolitik under ressourceknaphed (Vol. Report no. 3, pp. 310): Central Control, Local Communities and Local Politics.

Teigen, H. (2011). Distriktspolitikkens historie: Frå nasjonal strategi til regional fragmentering? Plan, 43(06), pp. 48-54. Retrieved from http://www.idunn.no/plan/2011/06/art08

Torcal, M. (2014). The decline of political trust in Spain and Portugal: economic performance or political responsiveness? American Behavioral Scientist, 58(12), pp. 1542-1567.

Turper, S., \& Aarts, K. (2017). Political trust and sophistication: Taking measurement seriously. Social indicators research, 130(1), pp. 415-434.

Uslaner, E. M. (1999). Democracy and social capital. In M. Warren (Ed.), Democracy and trust (pp. 121-150). Cambridge: Cambridge University Press.

Uslaner, E. M. (2002). The moral foundations of trust Cambridge: Cambridge University Press.

Valen, H. (1973). Norway:‘no’to EEC. Scandinavian Political Studies, 8(A8), pp. 214-226.

Van der Brug, W., \& Van Praag, P. (2007). Erosion of political trust in the Netherlands: Structural or temporarily? A research note. Acta Politica, 42(4), pp. 443-458. 
Van der Meer, T. (2010). In what we trust? A multi-level study into trust in parliament as an evaluation of state characteristics. International review of administrative sciences, 76(3), pp. 517-536.

Van Ryzin, G. G. (2007). Pieces of a puzzle: Linking government performance, citizen satisfaction, and trust. Public Performance \& Management Review, 30(4), pp. 521535. 